\title{
Expression of estrogen receptors and enzymes involved in sex steroid metabolism in the rat tibia during sexual maturation
}

\author{
B C J van der Eerden ${ }^{1}$, C W G M Löwik ${ }^{2}$, J M Wit ${ }^{1}$ and \\ M Karperien ${ }^{\mathbf{1}, 2}$ \\ ${ }^{1}$ Department of Pediatrics, Leiden University Medical Center, Leiden, The Netherlands \\ ${ }^{2}$ Department of Endocrinology and Metabolic Diseases, Leiden University Medical Center, Leiden, The Netherlands \\ (Requests for offprints should be addressed to M Karperien, Department of Endocrinology and Metabolic Diseases and Department of Pediatrics, Leiden \\ University Medical Center, Building 1, Zone C4-R86, PO Box 9600, 2300 RC Leiden, The Netherlands; Email: karperien@lumc.nl) \\ (B C J van der Eerden is now at Department of Internal Medicine, Erasmus MC, Room Ee569, Dr Molewaterplein 50, 3015 GE Rotterdam, The Netherlands)
}

\begin{abstract}
Estrogens are essential for bone mass accrual but their role before sexual maturation has remained elusive. Using in situ hybridization and immunohistochemistry, we investigated the expression of both estrogen receptor (ER) $\alpha$ and $\beta$ mRNA and protein as well as several mRNAs coding for enzymes involved in sex steroid metabolism (aromatase, type I and II 17 $\beta$-hydroxysteroid dehydrogenase (17ß-HSD), steroid sulfatase (STS) and type I $5 \alpha-$ reductase) on sections of tibial metaphyses before (1- and 4-week-old), during (7-week-old) and after (16-weekold) sexual maturation in female and male rats. ER $\alpha$ and ER $\beta$ mRNA and protein were detected in metaphyseal bone in lining cells, osteoblasts, osteoclasts and some osteocytes with no apparent differences in expression during development or between the sexes. In contrast, aromatase, type I and II $17 \beta-H S D$ and type I $5 \alpha$-reductase mRNAs were first detected in osteoblasts, osteoclasts and occasionally in osteocytes from sexual maturation (7week-old rat) and onwards. Only STS was present before sexual maturation. To study the significance of $\operatorname{ER} \alpha$ and $\beta$
\end{abstract}

expression in bone before sexual maturation when circulating sex steroid levels are low, 26-day-old female and male rats underwent gonadectomy or $17 \beta$-estradiol $\left(E_{2}\right)$ supplementation $(0.5 \mathrm{mg} / 21$ days $)$ during 3 weeks. Following gonadectomy, trabecular bone volume (TBV) was lower in males $(P=0.03)$ and there was a trend towards reduction in females $(P=0 \cdot 057) . \mathrm{E}_{2}$ supplementation increased tibial TBV compared with controls in both genders as assessed by Masson-Goldner staining. These data suggest that the presence of ERs in bone cells before sex maturation might be of significance for bone mass accrual. Furthermore, based on the mRNA expression of the crucial enzymes aromatase and type I $17 \beta-H S D$, we suggest that bone cells in the tibial metaphysis acquire the intrinsic capacity to metabolize sex steroids from sexual maturation onwards. This process may contribute to the beneficial effects of estrogen on bone mass accrual, possibly by intracrinology.

Journal of Endocrinology (2004) 180, 457-467

\section{Introduction}

Recent clinical observations in three male patients, one with an inactivating mutation in the estrogen receptor (ER) $\alpha$ and two with an aromatase enzyme deficiency have clearly established that estrogen is pivotal for bone mass accrual during puberty and bone metabolism in males and females (Smith et al. 1994. Morishima et al. 1995, Carani et al. 1997). Still, androgens seem to fulfill an essential role in establishing sexual differences in the skeleton, in both rats and humans (Turner et al. 1994b, Dagogo-Jack et al. 1997, Vanderschueren et al. 1998). Evidence is gathering that androgens and estrogens can exert direct effects on bone cells, since both ERs (ER $\alpha$ and $\mathrm{ER} \beta$ ) and androgen receptor (AR) mRNA and protein have been demonstrated in osteoblasts, lining cells, osteocytes and osteoclasts in several species, including the rat, rabbit and human (Braidman et al. 1995, 2001, Kusec et al. 1998, Noble et al. 1999, Vidal et al. 1999, Windahl et al. 2000, van der Eerden et al. 2002b). However, to date $\operatorname{ER} \alpha$ and $\operatorname{ER} \beta$ expression in the metaphysis of rat tibiae before and during sexual maturation has not been extensively studied.

The sex steroids acting on bone cells may either be derived from the circulation or be metabolized locally in bone by a process called 'intracrinology' (Labrie et al. 2000). It has been established in a number of studies that intracrinology can occur in various target tissues of sex steroids such as breast and brain, at least in humans (Labrie et al. 2000). A number of key enzymes are involved in the 
metabolism of the sulfated precursors dihydroepiandrosterone sulfate (DHEA-S) and estrone sulfate $\left(\mathrm{E}_{1}-\mathrm{S}\right)$, which are present in high amounts in the circulation, into the active metabolites testosterone and $17 \beta$-estradiol $\left(\mathrm{E}_{2}\right)$. Steroid sulfatase (STS) catalyzes the formation of DHEA and $E_{1}$ from the sulfated precursors, DHEA-S and $E_{1}-S$ respectively. Furthermore, type I $17 \beta$-hydroxysteroid dehydrogenase (17 $\beta-\mathrm{HSD})$ converts androstenedione into testosterone and $\mathrm{E}_{1}$ into $\mathrm{E}_{2}$, whereas type II catalyzes the conversion in the opposite direction. Aromatase mediates the conversion of the androgens, androstenedione and testosterone into the estrogens, $\mathrm{E}_{1}$ and $\mathrm{E}_{2}$. Finally, type I $5 \alpha$-reductase irreversibly converts testosterone into dihydrotestosterone. In primary cultures of rat osteoblasts, rat and human osteoblastic cell lines and in spongiosa obtained from patients undergoing orthopedic surgery, the mRNA expression and bioactivity of the enzymes aromatase, type I and II $17 \beta-$ HSD, STS and $5 \alpha$-reductase have all been demonstrated (Schweikert et al. 1995, Dong et al. 1998, Eyre et al. 1998, Saito \& Yanaihara 1998, Janssen et al. 1999, Feix et al. 2001). Moreover, using in situ hybridization and immunohistochemistry, Sasano et al. (1997) have localized aromatase mRNA and protein and type I $17 \beta-H S D$ immunoreactivity in lining cells and osteoblasts in sections of 16 human tibiae. This finding was confirmed for aromatase in a study by $\mathrm{Oz}$ et al. (2001). These data suggest that intracrinology might be an important source for bioactive sex steroids involved in bone metabolism. Until now, no reports have shown age-related expression of any of these enzymes in rat bone, particularly around sexual maturation.

Numerous studies have been performed to gain insight in the mechanism by which estrogens regulate bone mass. Many of these have focused on the postmenopausal bone loss in humans by using aged ovariectomized (OVX) rats or mice, when there is active bone remodeling (Wronski et al. 1986, Bagi et al. 1993). These models, however, are not suitable to study bone mass accrual during growth. Some studies have used younger animals, ranging between 6 weeks and 4 months, in which predominantly bone modeling takes place instead of remodeling. During this phase, high doses of estrogen have been described to increase trabecular bone volume (TBV) in 8-week-old OVX and 3-month-old intact female rats (both $4 \mathrm{mg} / \mathrm{kg}$ per day) (Tobias et al. 1991, Chow et al. 1992). These animals are, however, already sexually maturing or mature, at the start of the experiment. To date, little is known about the effects of estrogen withdrawal or supplementation before sexual maturation, when endogenous sex steroid levels are low $(<35 \mathrm{pg} / \mathrm{ml})$ or undetected (Dohler \& Wuttke 1976, Saksena \& Lau 1979) but bone mass accrual is high. Two studies have reported bone loss in mandibular condyles and in the temperomandibular joint after OVX in rats before or during early sexual maturation (Okuda et al. 1996, Yamashiro \& TakanoYamamoto 1998).
In this study we have focused on three topics. Using in situ hybridization and immunohistochemistry, we have surveyed the mRNA and protein expression of both ERs in the tibial metaphysis before, during and shortly after sexual maturation in female and male rats. Moreover, we studied the mRNA expression of various key enzymes involved in sex steroid biosynthesis in the tibial metaphysis at the same timepoints. Finally, we analyzed the effects of gonadectomy and $\mathrm{E}_{2}$ supplementation on $\mathrm{TBV}$ in the proximal metaphysis of tibiae from female and male rats starting just before sexual maturation when circulating levels of sex steroids are low.

\section{Material and methods}

\section{Animals}

Female and male Wistar rats were obtained from Harlan (Broekman Instituut, Someren, The Netherlands). They were kept in a light- and temperature-controlled room (12 h light, $\left.20-22^{\circ} \mathrm{C}\right)$ with food and water freely available. Experiments were approved by the local ethical committee for animal experiments.

\section{Experiment 1}

The animals $(n=4)$ were killed at 1, 4, 7 and 16 weeks of age by in vivo fixation (2\% paraformaldehyde in $0 \cdot 1 \mathrm{M}$ phosphate buffer supplemented with $75 \mathrm{mM}$ lysine monohydrochloride and $10 \mathrm{mM} \mathrm{Na}$ periodate) as described previously (van der Eerden et al. 2000). Tibiae were isolated and fixed in the same fixative for $24 \mathrm{~h}$. Then the tibiae were decalcified in 15\% EDTA, including 0.5\% paraformaldehyde for 4 weeks. Tibiae were cut into halves in a sagittal orientation, processed for paraffin embedding and $5 \mu \mathrm{m}$ sections were cut mid-sagittally.

\section{Experiment 2}

Twelve 26-day-old female and 12 male Wistar rats were ovariectomized by the dorsal approach under $\mathrm{O}_{2} / \mathrm{N}_{2} /$ halothane anesthesia $(n=5)$, orchidectomized $(n=6)$ or sham-operated (females, $n=7$; males, $n=6$ ). Rats enter sexual maturation at around day 30, which lasts about 4 weeks (Tanner 1962). This means that at the start of the experiment rats were still sexually immature. Three weeks later, when the rats were halfway through sexual maturation, the animals were killed using a fatal dose of Nembutal (Sanofi Sante Animale, Maassluis, The Netherlands). Animals from each experimental group were fixed in vivo and tibiae were processed as mentioned above.

\section{Experiment 3}

Twelve 26-day-old female and 12 male Wistar rats (female average body weight: $63.2 \mathrm{~g}(56 \cdot 4-68 \cdot 8 \mathrm{~g})$; male average 
Table 1 Overview of cRNA probes used for in situ hybridization. Indicated are the probe, the cloning vector in which the cDNA fragment was inserted, the size of the probe, the rat sequence nucleotides to which the probe corresponds and the concentration of sense (S) and antisense (AS) probes used in the in situ hybridization protocol

\begin{tabular}{|c|c|c|c|c|}
\hline & Vector & $\begin{array}{l}\text { Size } \\
\text { (bp) }\end{array}$ & Nucleotides & $\begin{array}{l}\text { Concentration } \\
(\mathrm{pg} / \mu \mathrm{l})\end{array}$ \\
\hline \multicolumn{5}{|l|}{ Probe } \\
\hline Aromatase & pBluescript SK- & 300 & 539-838 & S: 80, AS: 80 \\
\hline $17 \beta-H S D$ type I & pBluescript SK- & 602 & $1-602$ & S: 133, AS: 120 \\
\hline $17 \beta$-HSD type II & pExCell & 1289 & 1-1289 & S: 200, AS: 200 \\
\hline $5 \alpha$-Reductase & pBluescript SK- & 344 & 991-1334 & S: 133, AS: 200 \\
\hline STS & pBluescript SK- & 252 & $472-723$ & S: 200, AS: 200 \\
\hline ER- $\alpha$ & pBluescript SK- & 488 & $1250-1737$ & S: 750, AS: 1500 \\
\hline$E R-\beta$ & pBluescript KS & 391 & $1-391$ & S: 1500, AS: 1500 \\
\hline
\end{tabular}

body weight: $78 \cdot 8 \mathrm{~g}(69 \cdot 2-90 \cdot 8 \mathrm{~g}))$ were implanted with a slow-release pellet (Innovative Research of America, Saratosa, FL, USA) s.c. between the scapulae, releasing $0 \cdot 5 \mathrm{mg} \mathrm{E}_{2}(n=6)$ over a 21 day period. The control groups received a placebo pellet $(n=6)$. After 3 weeks, the animals were killed using a fatal dose of Nembutal, fixed in vivo and their tibiae were processed as mentioned above.

\section{Generation of cRNA probes for in situ hybridization}

In situ hybridization probes for $\operatorname{ER} \alpha$ and $\beta$ have been described in detail in a previous study (van der Eerden et al. 2002b). The probes for rat aromatase, type I and II $17 \beta$-HSD, STS and type I $5 \alpha$-reductase have all been described recently (van der Eerden et al. 2002a). Table 1 contains an overview of the cRNA probes, which were used in this study. Vector $(10 \mu \mathrm{g})$ was linearized with the appropriate restriction enzymes. The probes were labeled with digoxigenin (DIG) (Roche, Basel, Switzerland) as described before (van der Eerden et al. 2002b) and hydrolyzed to reduce the probe size to $200 \mathrm{bp}$ as described in detail by Wilkinson (1992). To assess the efficiency of probe labeling, dot blotting was performed as set out previously (van der Eerden et al. 2002b).

\section{In situ hybridization and control hybridizations}

We used the method described in detail previously (van der Eerden et al. 2002b) with some modifications. Briefly, sections were deparaffinized and incubated with $5 \mu \mathrm{g} / \mathrm{ml}$ (aromatase, type I and II $17 \beta-H S D$ and STS) or $10 \mu \mathrm{g} / \mathrm{ml}$ ( $5 \alpha$-reductase) proteinase K (Life Technologies, Breda, The Netherlands). After washing, hybridization was performed overnight at $50{ }^{\circ} \mathrm{C}$ (aromatase, type I 17 $\beta$-HSD and STS) or $60^{\circ} \mathrm{C}$ (type II $17 \beta$-HSD and $5 \alpha$-reductase). The hybridization mixture consisted of $50 \%$ formamide, $2 \times$ SSC, $1 \times$ Denhardt solution, $10 \%$ dextran sulfate, $1 \mathrm{mg} / \mathrm{ml}$ yeast tRNA and the probe of interest (see Table
1). All probes contained a similar amount of incorporated DIG-UTP as assessed by dot blot. After hybridization, and RNase A $(20 \mu \mathrm{g} / \mathrm{ml})$ (Sigma) treatment, sections were blocked in sheep serum. Alkaline phosphatase-conjugated anti-DIG (1:1250) (Roche) was applied overnight at $4{ }^{\circ} \mathrm{C}$ and staining was performed in a Nitro Blue Tetra zolium chloride/5-bromo-4-chloro-3-indolyl phosphate toluidine salt solution (Roche) varying from $6 \mathrm{~h}$ to overnight. Finally, the sections were counterstained with $0 \cdot 8 \%$ Methyl Green (ERs) or 0.5\% Neutral Red (enzymes), dehydrated and mounted in Euparal (Klinipath, Köngen, Germany). Statements on the mRNA expression patterns over time and between the sexes were based on the analysis of multiple tissue sections of four animals (at least two sections of each animal) in each experimental group. Representative pictures of the growth plate sections were taken with a Nikon DXM 1200 digital camera using the same settings.

\section{Immunohistochemistry}

The immunohistochemical protocol performed was identical to that published earlier (van der Eerden et al. 2002b). The antibodies for ER $\alpha$ and ER $\beta$ (MC-20 and Y-19 respectively; Santa Cruz Biotechnology, Santa Cruz, CA, USA) have both been extensively tested for their specificity in positive control tissues and by preincubation with corresponding peptides as negative controls (van der Eerden et al. 2002b). In short, after digestion with pepsin and blocking, sections were incubated overnight at $4{ }^{\circ} \mathrm{C}$ with the rabbit polyclonal MC-20 (1:50) or goat polyclonal Y-19 (1:50) as primary antibody in 0.5\% blocking buffer. After a number of secondary antibody steps, staining was visualized with 3 -amino-g-ethylcarbazole $(0 \cdot 2 \mathrm{mg} / \mathrm{ml}$ in acetate buffer $\mathrm{pH} 5 \cdot 2$ with $0 \cdot 04 \% \mathrm{H}_{2} \mathrm{O}_{2}$; Sigma) for $3 \mathrm{~min}$. After counterstaining with hematoxylin, the sections were embedded in Aquamount (BDH, Poole, Dorset, UK). Statements on protein expression patterns over time and 
between the sexes were based on the analysis of multiple tissue sections of four animals (at least two sections per animal) in each experimental group. Pictures of growth plate sections were taken with a Nikon DXM 1200 digital camera using the same settings.

\section{Staining according to the Masson-Goldner method}

Two $5 \mu \mathrm{m}$ thick mid-sagittal sections of the tibial metaphysis from all experimental groups $(n=6)$ underwent trichrome staining according to the Masson-Goldner method (Clark 1981). Sections were deparaffinized and washed in distilled water for $5 \mathrm{~min}$. Nuclei were stained in 1\% Mayer's hematoxylin (Merck, Darmstadt, Germany) for $40 \mathrm{~s}$ and directly washed for $10 \mathrm{~min}$ in running tap water. Next, sections were stained with Azophloxin (Merck) for $5 \mathrm{~min}$ and rinsed in 1\% acetic acid. Then, 2\% Orange G (Merck) solution was applied to the slides for 3 min followed by another rinse in 1\% acetic acid. Counterstaining was performed with $0 \cdot 2 \%$ Light Green (Sigma) for $15 \mathrm{~min}$, followed by a rinse in 1\% acetic acid. After dehydration, the sections were mounted in Histomount (National Diagnostics, Atlanta, GA, USA). Representative pictures of the tibial metaphyses just below the proximal growth plate were taken from all experimental groups. These were converted to grayscale images and black and white images, and from these TBV was determined and expressed as a percentage of total bone volume. Values were averaged \pm S.D. and differences between groups were analyzed for significance, using the Student's $t$-test. A $P$ value less than $0 \cdot 05$ was considered significant.

\section{Results}

Expression of ERa and ER $\beta m R N A$ and protein in the tibial metaphysis

In order to identify bone cells in the rat tibial metaphysis, which express ERs, in situ hybridization with specific cRNA probes was performed on sections of the proximal tibiae from 1-, 4-, 7- and 16-week-old modeling female and male rats $(n=4)$. Both ER $\alpha$ and ER $\beta$ mRNA were detected in osteoblasts, lining cells and osteoclasts during development as exemplified in a female rat at 4 weeks of age (ER $\alpha$ : Fig. $1 \mathrm{~A}$ and B; ER $\beta$ : Fig. $1 \mathrm{D}$ and $E)$. In osteocytes, we detected neither $\operatorname{ER} \alpha$ nor $\operatorname{ER} \beta$ mRNA. Control experiments using the respective sense probes did not reveal staining in any sections (Fig. $1 \mathrm{C}$ and $\mathrm{F}$ respectively). The expression of both ER mRNAs in bone did not change with time and did not differ between female and male rats. Immunohistochemically, the MC-20 (ER $\alpha)$ and $Y-19$ antibody $(E R \beta)$ were used to detect the ERs in the tibial metaphysis. The staining patterns for both ER proteins overlapped with the mRNA expression patterns. Some nuclear but predominantly cytoplasmic staining was observed in osteoblasts, lining cells and osteoclasts using both antibodies as exemplified in a 4-week-old female rat (ER $\alpha$, Fig. $1 \mathrm{G}$ and $\mathrm{H}$; ER $\beta$, Fig. $1 \mathrm{~J}$ and $\mathrm{K}$ ). In addition, a few ER $\alpha$ - and ER $\beta$-positive osteocytes were found (Fig. $1 \mathrm{G}$ and $\mathrm{J}$ and $\mathrm{K}$ respectively). Analysis of multiple tissue sections from each age group $(n=4)$ and from both sexes, did not reveal a difference in immunostaining between the sexes and over time. Control experiments in which the first antibody was omitted or the sections were preincubated with blocking peptides resulted in absence of staining (Fig. 1I and L). In a previous study, we have extensively described the specificity of the probes and antibodies, using positive control tissues such as uterus and ovary (van der Eerden et al. 2002b).

\section{Expression of enzymes involved in sex steroid metabolism in the tibial metaphysis}

We next examined the mRNA expression of various enzymes involved in sex steroid metabolism at the same timepoints, using in situ hybridization (Fig. 2). No differences of the enzyme mRNA expression patterns were observed between females and males, based on the analysis of at least two tissue slides from each animal $(n=4)$ in all age groups. The mRNAs for aromatase (Fig. 2A-D), type I (Fig. 2E-G) and type II 17ß-HSD (Fig. 2H-K), STS (Fig. $2 \mathrm{~L}-\mathrm{O}$ ) and type I $5 \alpha$-reductase (Fig. 2P-S) were all expressed in the metaphysis during and after sexual maturation as exemplified in female rats at 7 (Fig. 2A, B, E, H, I, L, M, P and Q) and 16 weeks of age (Fig. 2C, D, $\mathrm{F}, \mathrm{J}, \mathrm{K}, \mathrm{N}, \mathrm{O}, \mathrm{R}$ and $\mathrm{S}$ ) respectively. In contrast, before sexual maturation at 1 and 4 weeks of age, none of the enzyme mRNAs were detected except STS, which was already present in 1-week-old rats onwards (data not shown). The mRNA expression of all enzymes was predominantly observed in osteoblasts (Fig. 2A, C, E, H, J, L, N, P and R) and osteoclasts (Fig. 2B, D, G, I, K, M, $\mathrm{O}, \mathrm{Q}$ and $\mathrm{S}$ ) and occasionally in osteocytes (Fig. 2A, L and Q). Type I $17 \beta-H S D$ mRNA was only detected in osteoblasts and not in osteoclasts at 7 weeks of age (data not shown), whereas at 16 weeks of age osteoclasts were weakly positive (Fig. 2G). In control experiments, no staining was observed using sense cRNA probes for aromatase, type I and II $17 \beta-\mathrm{HSD}$, STS and $5 \alpha$-reductase (Fig. 2T-X respectively). We have recently described control experiments, demonstrating the specificity of the enzyme cRNA probes in uterus, ovary and prostate tissue (van der Eerden et al. 2002c).

\section{Effect of gonadectomy and $E_{2}$ supplementation on TBV before sexual maturation}

We showed that both ERs were expressed in the metaphysis before sexual maturation, while the various enzymes involved in sex steroid metabolism were not present. Taken together with observations that endogenous sex steroid levels are very low or undetected before 


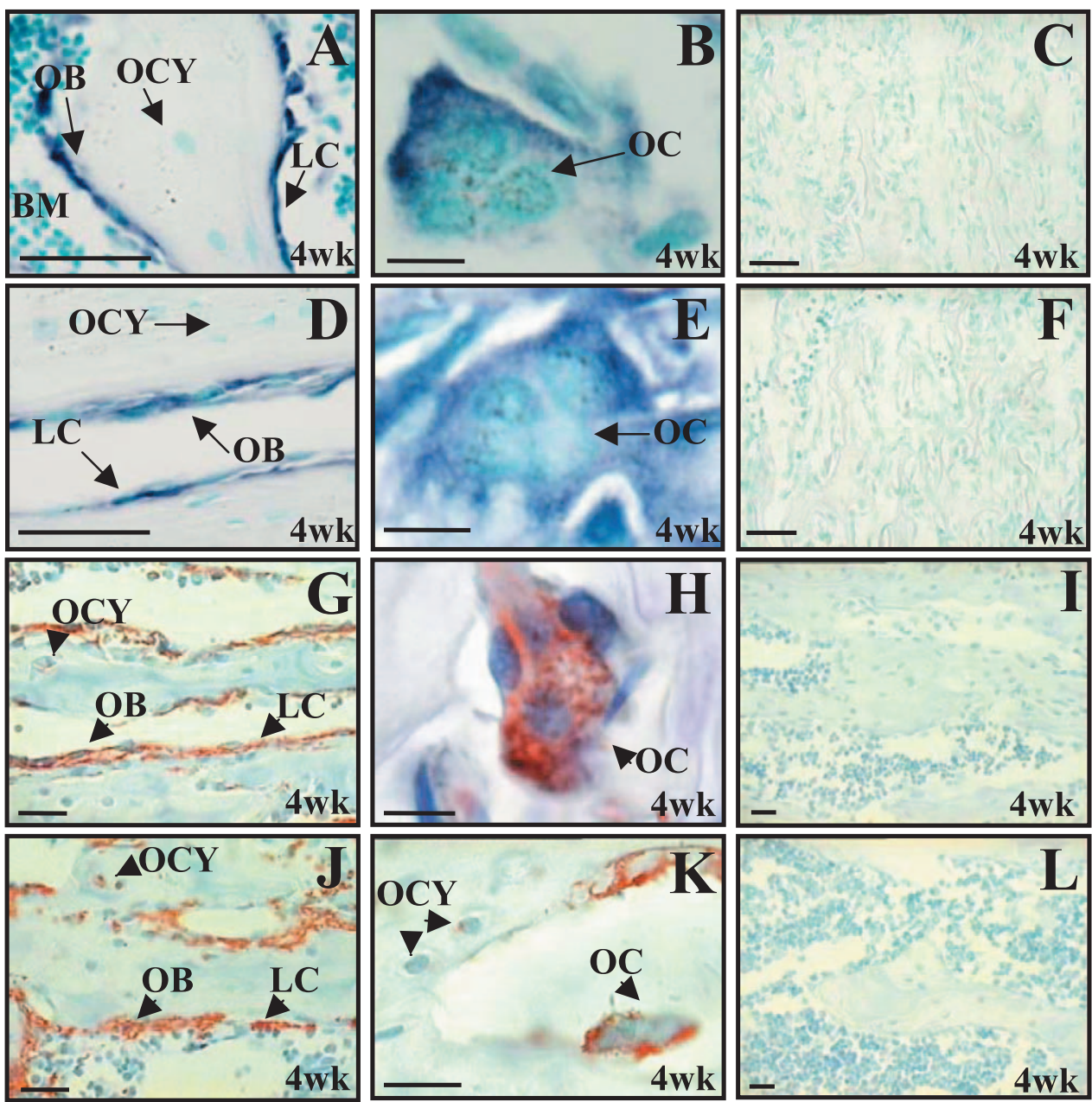

Figure 1 In situ hybridization and immunohistochemistry of $E R \alpha$ and $\beta$ in the tibial metaphysis of the rat. ER $\alpha$ and $\beta$ mRNA were expressed in lining cells, osteoblasts ( $A$ and D respectively) and in osteoclasts (B and $E$ respectively) as exemplified in a 4-week-old rat. Both $E R \alpha$ and $\beta$ mRNA were not detected in osteocytes (A and D respectively). Arrows indicate the different cell types. Sense hybridizations for ER $\alpha$ (C) and ER $\beta$ (F) demonstrated absence of signal in bone. Staining for ER $\alpha$ with the MC-20 antibody and for ER $\beta$ with the Y-19 antibody was observed in lining cells, osteoblasts ( $G$ and J respectively) and in osteoclasts ( $\mathrm{H}$ and $\mathrm{K}$ respectively) as exemplified in a 4-week-old rat. Both $\mathrm{ER} \alpha$ and $\beta$ were occasionally detected in osteocytes ( $\mathrm{G}$ and $\mathrm{J}$ and $\mathrm{K}$ respectively). Arrowheads indicate the different cell types. Preincubation of MC-20 or Y-19 antibody with a blocking peptide ( $\mathrm{I}$ and $\mathrm{L}$ respectively), resulted in absence of staining. Bar represents $50 \mu \mathrm{m}(\mathrm{A}, \mathrm{C}, \mathrm{D}, \mathrm{F}, \mathrm{G}, \mathrm{I}-\mathrm{L})$ or $10 \mu \mathrm{m}(\mathrm{B}, \mathrm{E}, \mathrm{H})$. Abbreviations: OB, osteoblast; LC, lining cell; OCY, osteocyte; OC, osteoclast; BM, bone marrow.

sexual maturation in the rat (Saksena \& Lau 1979), we assessed the functional significance of the ERs in the metaphysis at this stage. Therefore, 26-day-old female and male rats were either gonadectomized or supplemented with $\mathrm{E}_{2}$. In general, rats enter the sexual maturation stage around day 30 (Tanner 1962), indicating that in our experiments rats were still sexually immature at the start of the experiment.

Gonadectomy of 26-day-old rats resulted in a lower TBV as assessed by Masson-Goldner staining in males $(8 \cdot 85 \pm 1.91$ vs $18 \cdot 1 \pm 7 \cdot 72 \% ; P=0.030)$ and a trend towards a lower TBV in females (Fig. 3A; $7 \cdot 62 \pm 3 \cdot 18$ vs $13 \cdot 3 \pm 4 \cdot 80 \% ; P=0 \cdot 057)$ compared with controls.

When $\mathrm{E}_{2}$ was administered to 26-day-old rats via slow-release pellets during 3 weeks, the opposite occurred; compared with placebo, a strong increase in TBV was evident in females (Fig. 3A; $28 \cdot 8 \pm 12 \cdot 6$ vs $12 \cdot 2 \pm 2 \cdot 59 \%$; $P=0.042)$ and males $(37 \cdot 7 \pm 7 \cdot 57$ vs $21.9 \pm 1 \cdot 79 \%$; $P<0 \cdot 001)$. Representative black and white images from each group of both experiments exemplify the histogram (Fig. 3B). OVX (Fig 3B, b) and orchidectomy (d) demonstrated lower TBV compared with sham-operated 


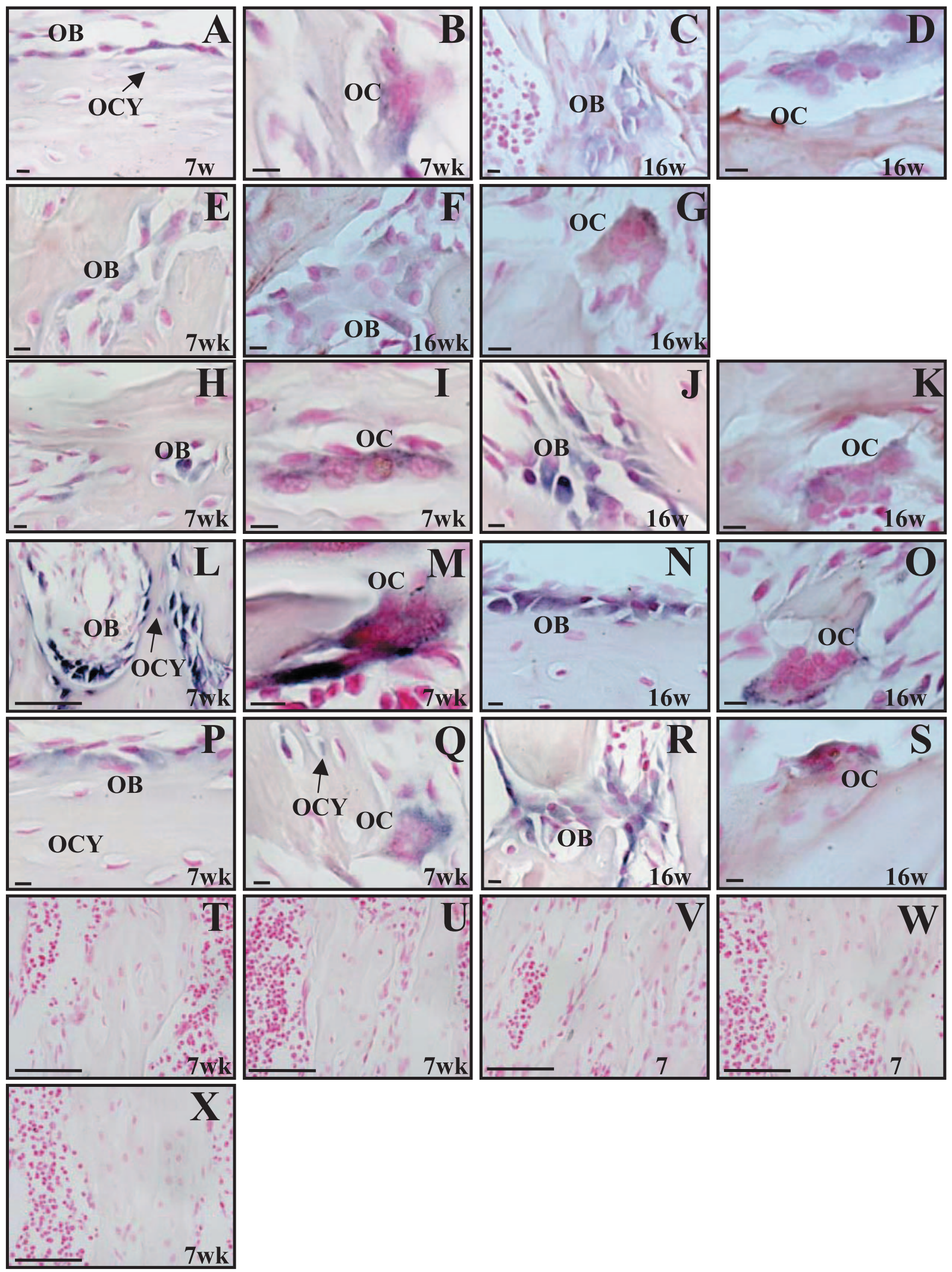


animals (a and c respectively), whereas $\mathrm{E}_{2}$ supplementation increased TBV in females (f) and males (h) compared with placebo (e and g respectively).

The TBV of sham-operated and placebo-control rats in the two experiments were not significantly different (females: $13 \cdot 3 \pm 4 \cdot 80$ vs $12 \cdot 2 \pm 2 \cdot 59 \%, P=0 \cdot 69$; males: $18 \cdot 1 \pm 7 \cdot 72$ vs $21 \cdot 9 \pm 1 \cdot 79 \%, P=0 \cdot 43)$. As expected, TBV values of males in the control group were higher compared with females in both experiments but only significant in the $\mathrm{E}_{2}$-supplementation experiment (gonadectomy experiment: $18 \cdot 1 \pm 7 \cdot 72$ vs $13 \cdot 3 \pm 4 \cdot 80 \%, P=0 \cdot 21 ; \mathrm{E}_{2^{-}}$ supplementation experiment: $21 \cdot 9 \pm 1 \cdot 79 \%$ vs $12 \cdot 2 \pm$ $2 \cdot 59 \%, P<0 \cdot 001)$.

The effects of gonadectomy and $\mathrm{E}_{2}$ supplementation on other parameters in these animals, such as longitudinal growth, body weight gain, growth plate thickness and development of the gonads are described elsewhere (van der Eerden et al. 2002a).

\section{Discussion}

Several studies have established that sex steroids can exert direct effects on bone cells, since receptors for estrogen and androgen have been demonstrated in lining cells, osteoblasts, osteocytes and osteoclasts. To date, however, no studies have thoroughly investigated the expression of both ERs before, during and after sexual maturation in bone. Furthermore, it is unclear whether metabolism of sex steroids in bone cells can occur at these timepoints. To address these issues, we have performed a systematic survey of ER $\alpha$ and $\beta$ mRNA and protein expression in the tibial metaphysis, using in situ hybridization and immunohistochemistry on tibial sections from 1-, 4-, 7- and 16-week-old female and male rats. Furthermore, we studied the mRNA expression of various enzymes in sex steroid metabolism, aromatase, type I and II $17 \beta-\mathrm{HSD}$, STS and $5 \alpha$-reductase in the same age groups. These stages are characterized by fast growth and bone mass accrual before (1 and 4 weeks) and during sexual maturation ( 7 weeks), followed by bone modeling at a lower pace after sexual maturation (16 weeks). Not until 9 months of age does bone modeling comes to an end and bone remodeling becomes predominant in rats (Wang et al. 2001).
We demonstrate that both ERs are present in osteoblasts, osteoclasts and some osteocytes of the tibial metaphysis irrespectively of age and gender. The mRNA of various key enzymes involved in sex steroid metabolism were also present in bone-forming and -degrading cells, however, only from week 7 and onwards, with the exception of STS mRNA, which was present at all timepoints.

ER $\alpha$ and $\beta$ mRNA and protein were predominantly expressed in lining cells, osteoblasts and osteoclasts and occasionally in osteocytes, irrespectively of age and gender. Expression of ER $\alpha$ in cultured human osteoblast-like cells and osteoclasts is well documented (Arts et al. 1997, Onoe et al. 1997, Gruber et al. 1999), but localization of ER $\alpha$ in bone tissue sections is less well described. Kusec et al. (1998) found ER $\alpha$ mRNA in osteoblasts of rabbit and human bone only, whereas ER $\alpha$ has been shown in osteocytes of human, pig and guinea pig (Braidman et al. 1995). Another study reported very low levels of ER $\alpha$ mRNA in human osteocytes (Hoyland et al. 1997). Apparently, localization of ER $\alpha$ on osteoblasts and osteocytes, but in our hands also osteoclasts, depends on the species, protocol and/or the antibody used to detect the receptor.

ER $\beta$ mRNA expression was reported in osteoblasts of neonatal rat bone (Windahl et al. 2000), whereas the protein was present in mouse and human osteoblasts, osteoclasts and osteocytes (Vidal et al. 1999, Braidman et al. 2001), which agrees well with our findings. Our expression data imply that estrogen can exert its regulatory role in bone modeling directly on both bone-forming and -degrading cells in the female and male rat during development starting from 1 week after birth. Expression of both ERs did not seem to alter during sexual maturation, suggesting that regulation of the ERs by rising levels of circulating estrogen might not occur in metaphyseal bone at least at the mRNA and protein level. However, other more quantitative techniques should confirm this statement.

Aromatase, type I and II $17 \beta-H S D$, STS and $5 \alpha-$ reductase mRNA were also present in the metaphyseal bone of the rat. The enzymes were mainly detected in osteoblasts and osteoclasts but occasionally also in osteocytes, irrespective of gender. Interestingly, all enzyme mRNAs were expressed from sexual maturation (7 weeks

\footnotetext{
Figure 2 In situ hybridization of aromatase, type I and II 17ß-HSD, STS and 5 $\alpha$-reductase mRNA in the tibial metaphyses of the rat. In situ hybridization demonstrating aromatase (A-D), type I and II 17 $\beta-\mathrm{HSD}$ (E-G and H-K respectively), STS (L-O) and 5 $\alpha-$ reductase $(\mathrm{P}-\mathrm{S})$ mRNA in sections of tibial growth plates from female and male rats. Aromatase, type I 17 $\beta$-HSD, type II $17 \beta$-HSD, STS and $5 \alpha-$-reductase mRNA were all expressed in females at 7 ( $A$ and $B ; E ; H$ and $\mathrm{I} ; \mathrm{L}$ and $\mathrm{M} ; \mathrm{P}$ and $\mathrm{Q}$ respectively) and 16 weeks of age $(\mathrm{C}$ and $\mathrm{D} ; \mathrm{F} ; \mathrm{J}$ and $\mathrm{K}$; $\mathrm{N}$ and $\mathrm{O} ; \mathrm{R}$ and $\mathrm{S}$ respectively) and was predominantly found in osteoblasts ( $\mathrm{A}$ and $\mathrm{C} ; \mathrm{E} ; \mathrm{H}$ and $\mathrm{J} ; \mathrm{L}$ and $\mathrm{N} ; \mathrm{P}$ and $\mathrm{R} ;$ respectively), osteoclasts ( $\mathrm{B}$ and $\mathrm{D} ; \mathrm{G} ; \mathrm{I}$ and $\mathrm{K} ; \mathrm{M}$ and $\mathrm{O} ; \mathrm{Q}$ and $\mathrm{S}$ respectively) and occasionally in osteocytes (indicated with arrows in $\mathrm{A}$, $\mathrm{L}$ and $\mathrm{Q}$ ). Control hybridizations with sense RNA probes for aromatase (T) type I and II 17 $\beta$-HSD ( $\mathrm{U}$ and V respectively), STS (W) and 5 $\alpha$-reductase (X) showed no signal. Bar represents $50 \mu \mathrm{m}(\mathrm{L}, \mathrm{T}-\mathrm{X})$ or $10 \mu \mathrm{m}(\mathrm{A}-\mathrm{K}, \mathrm{L}-\mathrm{S})$. Abbreviations: OB, osteoblast; LC, lining cell; OCY, osteocyte; OC, osteoclast; BM, bone marrow.
} 


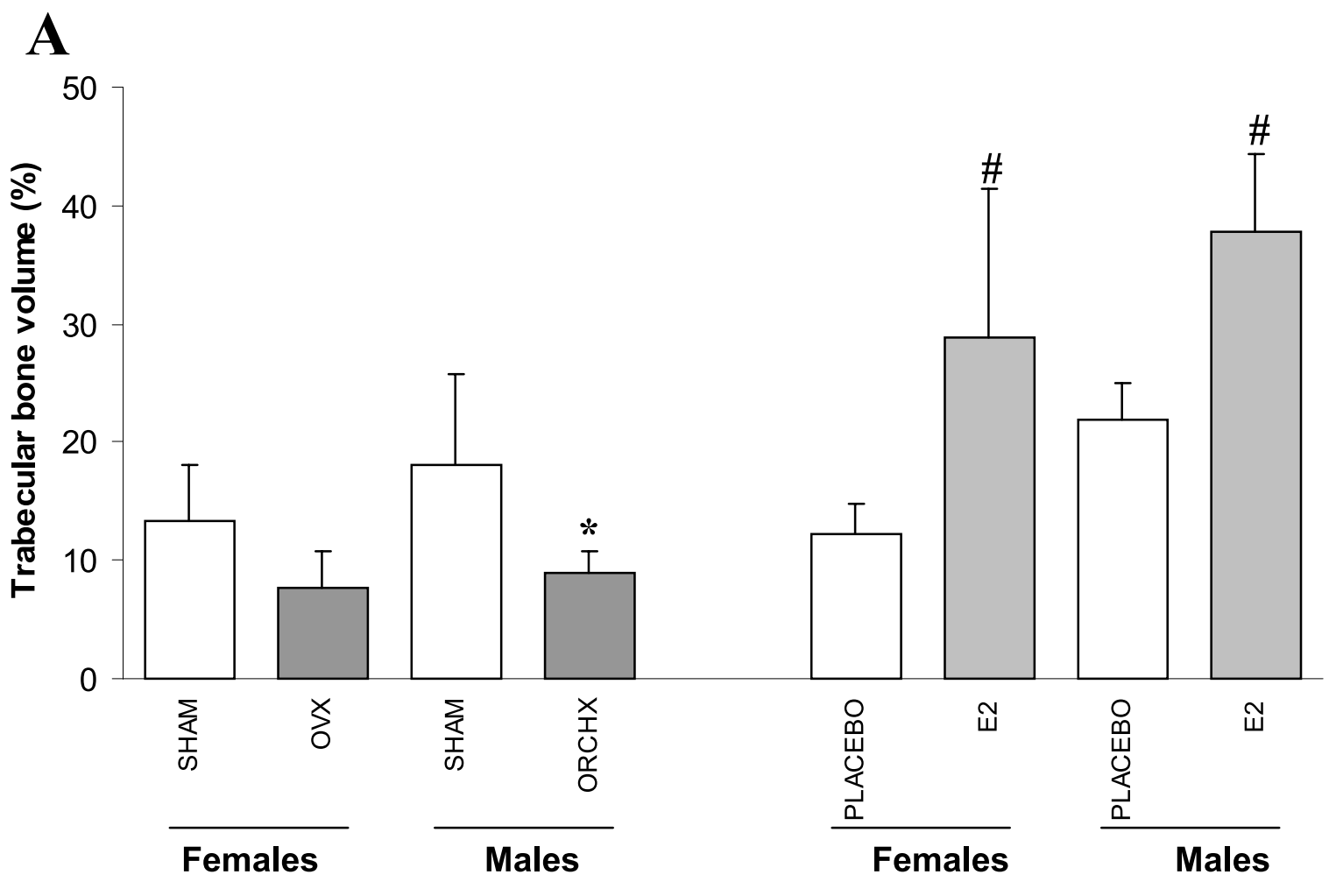

B
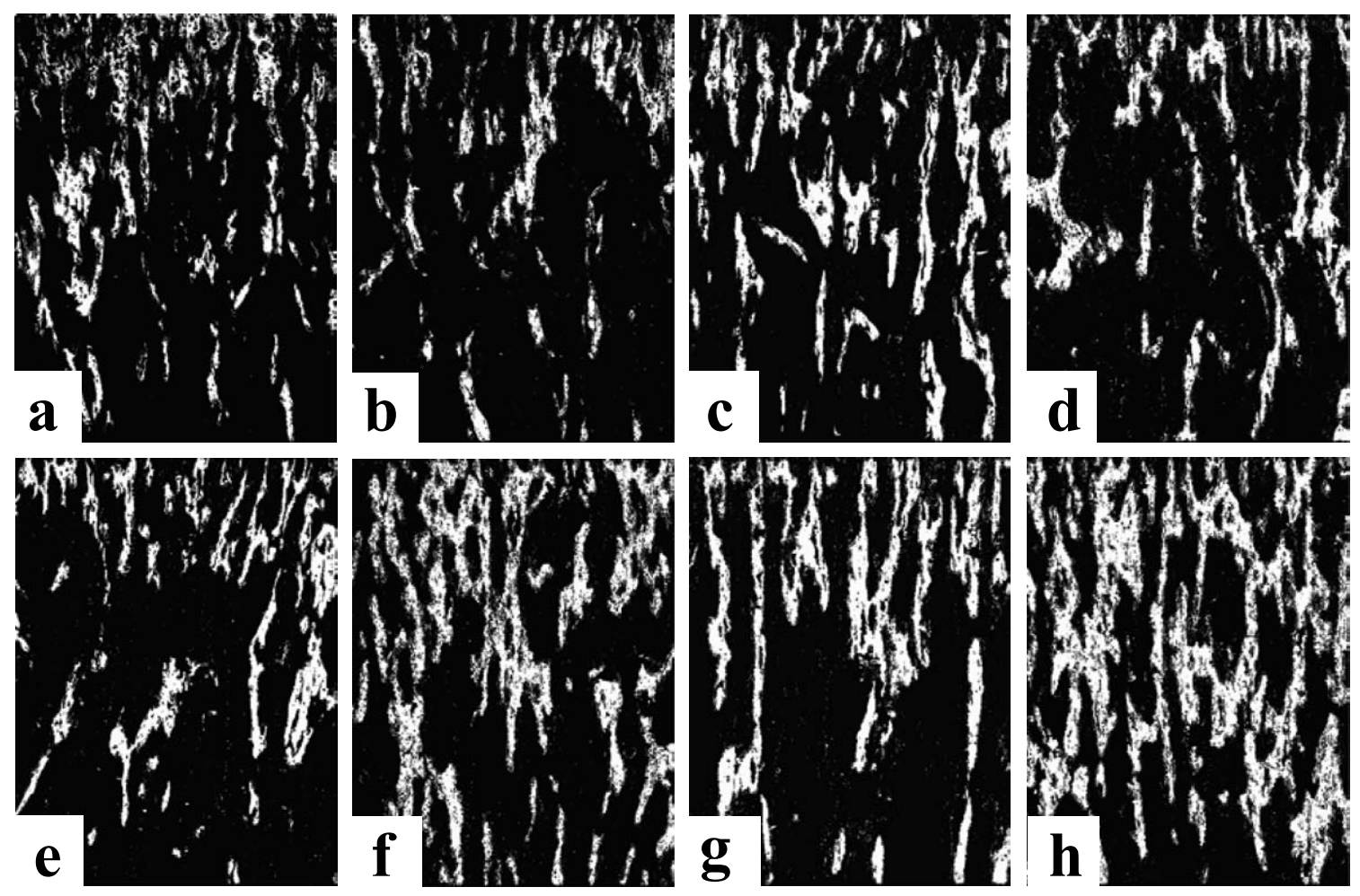
of age) and thereafter (16 weeks of age). In contrast, none of these enzymes was detected before sexual maturation (1 and 4 weeks of age), except for STS, which was already present from 1 week onwards.

Combining the findings in this study and of a recent paper by us (van der Eerden et al. 2002b), we have demonstrated co-expression of both ERs, AR and various enzymes involved in sex steroid metabolism, suggesting that intracrinology may take place in metaphyseal bone predominantly from the onset of sexual maturation onwards in the rat. Even before sexual maturation, low levels of circulating $\mathrm{E}_{1}-\mathrm{S}$ may be converted by the presence of STS. Local sex steroid metabolism may therefore play a role in the beneficial effects of $E_{2}$ on bone mass accrual, possibly by intracrinology.

Our findings are in line with other reports, indicating that intracrinology occurs in various target tissues of sex steroids including several brain regions, such as the amygdala and the cortex, and cultured hypothalamic neurons in the rat (Jacobson et al. 1997, Negri-Cesi et al. 2001). These and our findings are in disagreement with a recent paper claiming that sex steroids in rodents are exclusively formed in the gonads (Labrie et al. 2000).

Various other studies have reported expression and bioactivity of enzymes in human and rat bone cells, although these studies have mainly focused on the aging skeleton and/or osteoblastic cell lines and not on the modeling skeleton around sexual maturation (Dong et al. 1998, Eyre et al. 1998, Saito \& Yanaihara 1998, Feix et al. 2001). Sasano et al. (1997) have demonstrated aromatase and type I $17 \beta-\mathrm{HSD}$ protein as well as aromatase mRNA in osteoblasts and lining cells in bone derived from middle-aged or older adults. Only very recently, aromatase protein was found in osteoblasts and osteoclasts from human femoral material that was obtained from an adolescent male and female undergoing epiphysectomy to counter premature growth plate fusion in the opposite leg (Oz et al. 2001). To date, no other reports have localized aromatase in metaphyseal bone cells, nor any other enzyme investigated in this study.

By upregulating the expression/activity of various enzymes involved in estrogen metabolism around sexual maturation/puberty, high amounts of active estrogens could be formed locally. This may result in the increased rate of bone maturation that is evident during sexual maturation in rodents and during puberty in man. In support of this, in ER $\alpha$ - and aromatase-deficient patients, pubertal bone maturation and growth plate closure fail to occur (Smith et al. 1994, Morishima et al. 1995).

We should note, however, that we only examined mRNA expression of a number of enzymes involved in estrogen metabolism. Future studies should reveal whether this expression pattern associates with protein expression and enzyme activity. In a recent study, we observed an excellent correlation between mRNA expression and enzymatic activity in rat tibial chondrocytes of aromatase, type I 17ß-HSD and STS (van der Eerden et al. 2002c).

As both ERs were expressed in metaphyseal bone cells during sexual maturation, independently of the rising circulating levels of sex steroids, whereas the enzymes involved in sexual maturation were present from sexual maturation onwards, we investigated the functional relevance of the ERs in the metaphysis at this stage. To address this, the effect of gonadectomy or $\mathrm{E}_{2}$ supplementation on TBV was studied in 26-day-old female and male rats, which were sexually immature at the start of the experiment, whereas at the end of the experiment (3 weeks later) control rats were sexually maturing. Therefore, we cannot completely rule out sexual maturation effects on measurements in the metaphysis of control rats at the end of the experiment. However, as gonadectomized rats do not sexually mature due to the absence of sex steroids, whereas rats receiving $\mathrm{E}_{2}$ contain very high estrogen levels (approximately 1000-fold above endogenous levels), the interference of endogenous estrogen levels will be minimal.

Compared with controls, TBV was reduced (trend towards reduction in females) following gonadectomy and increased following $\mathrm{E}_{2}$ supplementation in both sexes. The observed findings coincide with other studies in rats before and during early sexual maturation, in which bone loss was observed in mandibular condyles and in the temperomandibular joint (Okuda et al. 1996, Yamashiro \& TakanoYamamoto 1998). Most studies, however, were performed in aged animals as models for postmenopausal bone loss, when bone remodeling instead of bone modeling is predominant (Wronski et al. 1986, Bagi et al. 1993, Turner et al. 1994b). The lack of a significant effect in females might be due to the fact that only during the latter half of the experiment are $\mathrm{E}_{2}$ levels different between sham and OVX animals. As a consequence, the time period during which $\mathrm{E}_{2}$ levels were low or absent was too short to observe a more pronounced effect on bone loss. Since $\mathrm{E}_{2}$ levels are low in males, the observed significant bone

Figure 3 Effects of gonadectomy and $\mathrm{E}_{2}$ supplementation on metaphyseal TBV in female and male rats. Female and male rats were either gonadectomized or supplemented with $\mathrm{E}_{2}$ for 3 weeks. Staining according to the Masson-Goldner method was performed on paraffin sections from animals of all experimental groups. After taking pictures of the metaphysis, they were converted to grayscale and subsequently into black and white images. Next, TBV was measured, depicted as means \pm S.D. from $n=5-7$ animals in each group (A). Representative black and white images are depicted to support the graph (B). Lower TBV was observed in OVX (b) and orchidectomized $\left(\mathrm{ORCHX)}(\mathrm{d})\right.$ compared with their sham-operated control rats (a and $\mathrm{c}$ respectively), whereas supplementation with $\mathrm{E}_{2}$ increased TBV in female and male rats ( $f$ and $h$ respectively) as opposed to the placebo controls (e and g respectively). ${ }^{*}$ Significance of $P<0 \cdot 05$ vs sham-operated (SHAM) animals of the same sex. Significance of ${ }^{\#} P<0 \cdot 05$ vs placebo controls of the same sex. 
loss may reflect reduced androgen signaling, rather than reduced estrogen signaling.

In our study, supraphysiological doses $(23 \mu \mathrm{g} /$ day $)$ of $E_{2}$ in 26-day-old intact rats dramatically increased TBV, in both females and males. This agrees well with other studies in rats during (Wakley et al. 1997) and just after sexual maturation (Tobias et al. 1991), although much higher doses were used compared with that in our study $(\sim 200$ vs $23 \mu \mathrm{g} /$ day). The anabolic effect of $E_{2}$ has been associated either with inhibited bone resorption, as observed in 7-week-old OVX rats (Turner et al. 1994a,b) or 2-monthold male rats (Wakley et al. 1997), or with increased bone formation, reported in 3-month-old female rats (Tobias et al. 1991). Our data do not provide an answer to whether the observed increase in TBV is due to enhanced formation or a reduction of resorption. The data also indicate that estrogen is not only important for bone mass accrual in female rats, but also in males. Clinical findings in male patients with an inactivating mutation of the ER gene and aromatase deficiency (Smith et al. 1994, Morishima et al. 1995, Carani et al. 1997) have shown that this also applies to humans.

Our data suggest that changes in the level of estrogen may have major effects on bone mass accrual, even just before sexual maturation when endogenous levels of estrogen are low or undetected (Saksena \& Lau 1979). At these timepoints, $E_{2}$ may have direct effects on bone cells themselves, since they express ERs, even before sexual maturation. However, $\mathrm{E}_{2}$ may also exert indirect effects on bone, e.g. by influencing the somatotropic axis. Indeed, it has been shown that $\mathrm{E}_{2}$ regulates the pulse and amplitude of growth hormone $(\mathrm{GH})$ secretion in humans (Veldhuis 1998). Furthermore, both GH and insulin-like growth factor-I have anabolic effects on bone (Ohlsson et al. 2000). Pro-apoptotic effects of $E_{2}$ have been reported for osteoclasts, and anti-apoptotic effects for osteoblasts and osteocytes, which play a role in prevention of postmenopausal bone loss by $\mathrm{E}_{2}$ (Greenfield et al. 1999, Kousteni et al. 2001). Whether these mechanisms contribute to the modeling skeleton is less clear and will be the subject of future research.

In conclusion, whereas both ERs are present in rat metaphyseal bone from birth onwards, various key enzymes involved in sex steroid metabolism are first present from sexual maturation onwards. This suggests that in metaphyseal bone the local formation of the most potent sex-steroids ( $E_{2}$ and testosterone) as well as intracrinology may play a significant role in bone mass accrual and maintenance starting from sexual maturation and thereafter.

\section{Acknowledgements}

We would like to express our gratitude to Dr Vihko (University of Oulu, Oulu, Finland) for providing us with the type I and II $17 \beta-H S D$ probes. We are grateful to Dr Cheng (Center for Biomedical Research, New York, USA) and Dr Russell (University of Texas, Southwestern Medical Center, Dallas, USA) for supplying us with the aromatase and the $5 \alpha$-reductase probe respectively.

\section{Funding}

This work was supported in part by a grant from the Gisela Thier Fund and by an unrestricted grant from Ferring BV, The Netherlands. There are no conflicts of interest in this study.

\section{References}

Arts J, Kuiper GG, Janssen JM, Gustafsson JA, Lowik CW, Pols HA \& van Leeuwen JP 1997 Differential expression of estrogen receptors alpha and beta mRNA during differentiation of human osteoblast SV-HFO cells. Endocrinology 138 5067-5070.

Bagi CM, Mecham M, Weiss J \& Miller SC 1993 Comparative morphometric changes in rat cortical bone following ovariectomy and/or immobilization. Bone 14 877-883.

Braidman IP, Davenport LK, Carter DH, Selby PL, Mawer EB \& Freemont AJ 1995 Preliminary in situ identification of estrogen target cells in bone. Journal of Bone and Mineral Research 10 74-80.

Braidman IP, Hainey L, Batra G, Selby PB, Saunders PT \& Hoyland JA 2001 Localization of estrogen receptor $\beta$ protein expression in adult human bone. Journal of Bone and Mineral Research 16 214-220.

Carani C, Qin K, Simoni M, Faustini-Fustini M, Serpente S, Boyd J, Korach KS \& Simpson ER 1997 Effect of testosterone and estradiol in a man with aromatase deficiency. New England Journal of Medicine 337 91-95.

Chow JW, Lean JM, Abe T \& Chambers TJ 1992 The anabolic effect of 17 beta-oestradiol on the trabecular bone of adult rats is suppressed by indomethacin. Journal of Endocrinology 133 189-195.

Clark G 1981 Staining Procedures, edn 4. Baltimore, MD and London: Williams \& Wilkins.

Dagogo-Jack S, al Ali N \& Qurttom M 1997 Augmentation of bone mineral density in hirsute women. Journal of Clinical Endocrinology and Metabolism 82 2821-2825.

Dohler KD \& Wuttke W 1976 Circadian fluctuations of serum hormone levels in prepubertal male and female rats. Acta Endocrinologica 83 269-279.

Dong Y, Qiu QQ, Debear J, Lathrop WF, Bertolini DR \& Tamburini PP 199817 Beta-hydroxysteroid dehydrogenases in human bone cells. Journal of Bone and Mineral Research 13 1539-1546.

van der Eerden BCJ, Karperien M, Gevers EF, Lowik CW \& Wit JM 2000 Expression of Indian hedgehog, parathyroid hormone-related protein, and their receptors in the postnatal growth plate of the rat: evidence for a locally acting growth restraining feedback loop after birth. Journal of Bone and Mineral Research 15 1045-1055.

van der Eerden BCJ, Emons J, Ahmed S, van Essen HW, Wit JM \& Karperien M 2002a Evidence for genomic and non-genomic actions of estrogens in growth plate regulation in female and male rats at the onset of sexual maturation. Journal of Endocrinology 175 277-288.

van der Eerden BCJ, Gevers EF, Lowik CW, Karperien M \& Wit JM $2002 b$ Expression of estrogen receptor $\alpha$ and $\beta$ in the epiphyseal plate of the rat. Bone $30478-485$.

van der Eerden BCJ, van de Ven J, Lowik CWGM, Wit JM \& Karperien M 2002c Sex steroid formation in the growth plate of the rat. Endocrinology 143 4048-4053. 
Eyre LJ, Bland R, Bujalska IJ, Sheppard MC, Stewart PM \& Hewison M 1998 Characterization of aromatase and 17 beta-hydroxysteroid dehydrogenase expression in rat osteoblastic cells. Journal of Bone and Mineral Research 13 996-1004.

Feix M, Wolf L \& Schweikert HU 2001 Distribution of 17 beta-hydroxysteroid dehydrogenases in human osteoblast-like cells. Molecular and Cell Endocrinology 171 163-164.

Greenfield EM, Bi Y \& Miyauchi A 1999 Regulation of osteoclast activity. Life Sciences 65 1087-1102.

Gruber R, Czerwenka K, Wolf F, Ho GM, Willheim M \& Peterlik M 1999 Expression of the vitamin D receptor, of estrogen and thyroid hormone receptor alpha- and beta-isoforms, and of the androgen receptor in cultures of native mouse bone marrow and of stromal/osteoblastic cells. Bone 24 465-473.

Hoyland JA, Mee AP, Baird P, Braidman IP, Mawer EB \& Freemont AJ 1997 Demonstration of estrogen receptor mRNA in bone using in situ reverse-transcriptase polymerase chain reaction. Bone $\mathbf{2 0}$ 87-92.

Jacobson NA, Ladle DR \& Lephart ED 1997 Aromatase cytochrome P450 and 5 alpha-reductase in the amygdala and cortex of perinatal rats. Neuroreport 8 2529-2533.

Janssen JM, Bland R, Hewison M, Coughtrie MW, Sharp S, Arts J, Pols HA \& van Leeuwen JP 1999 Estradiol formation by human osteoblasts via multiple pathways: relation with osteoblast function. Journal of Cellular Biochemistry 75 528-537.

Kousteni S, Bellido T, Plotkin LI, O’Brien CA, Bodenner DL, Han L, Han K, DiGregorio GB, Katzenellenbogen JA, Katzenellenbogen BS et al. 2001 Nongenotropic, sex-nonspecific signaling through the estrogen or androgen receptors: dissociation from transcriptional activity. Cell 104 719-730.

Kusec V, Virdi AS, Prince R \& Triffitt JT 1998 Localization of estrogen receptor-alpha in human and rabbit skeletal tissues. Journal of Clinical Endocrinology and Metabolism 83 2421-2428.

Labrie F, Luu-The V, Lin SX, Simard J, Labrie C, El Alfy M, Pelletier G \& Belanger A 2000 Intracrinology: role of the family of 17 beta-hydroxysteroid dehydrogenases in human physiology and disease. Journal of Molecular Endocrinology 25 1-16.

Morishima A, Grumbach MM, Simpson ER, Fisher C \& Qin K 1995 Aromatase deficiency in male and female siblings caused by a novel mutation and the physiological role of estrogens. Journal of Clinical Endocrinology and Metabolism 80 3689-3698.

Negri-Cesi P, Colciago A, Motta M, Martini L \& Celotti F 2001 Aromatase expression and activity in male and female cultured rat hypothalamic neurons: effect of androgens. Molecular and Cellular Endocrinology 178 1-10.

Noble B, Routledge J, Stevens H, Hughes I \& Jacobson W 1999 Androgen receptors in bone-forming tissue. Hormone Research $\mathbf{5 1}$ 31-36.

Ohlsson C, Jansson JO \& Isaksson O 2000 Effects of growth hormone and insulin-like growth factor-I on body growth and adult bone metabolism. Current Opinion in Rheumatology 12 346-348.

Okuda T, Yasuoka T, Nakashima M \& Oka N 1996 The effect of ovariectomy on the temporomandibular joints of growing rats. Journal of Oral and Maxillofacial Surgery 54 1201-1210.

Onoe Y, Miyaura C, Ohta H, Nozawa S \& Suda T 1997 Expression of estrogen receptor beta in rat bone. Endocrinology 138 4509-4512.

Oz OK, Millsaps R, Welch R, Birch J \& Zerwekh JE 2001 Expression of aromatase in the human growth plate. Journal of Molecular Endocrinology 27 249-253.
Saito H \& Yanaihara T 1998 Steroid formation in osteoblast-like cells. Journal of International Medical Research 26 1-12.

Saksena SK \& Lau IF 1979 Variations in serum androgens, estrogens, progestins, gonadotropins and prolactin levels in male rats from prepubertal to advanced age. Experimental Aging Research $\mathbf{5}$ 179-194.

Sasano H, Uzuki M, Sawai T, Nagura H, Matsunaga G, Kashimoto O \& Harada N 1997 Aromatase in human bone tissue. Journal of Bone and Mineral Research 12 1416-1423.

Schweikert HU, Wolf L \& Romalo G 1995 Oestrogen formation from androstenedione in human bone. Clinical Endocrinology 43 $37-42$.

Smith EP, Boyd J, Frank GR, Takahashi H, Cohen RM, Specker B, Williams TC, Lubahn DB \& Korach KS 1994 Estrogen resistance caused by a mutation in the estrogen-receptor gene in a man. New England Journal of Medicine 331 1056-1060.

Tanner JM 1962 The adolescent spurt in animals. In Growth at Adolescence, pp 223-239. Ed. CC Thomas. Oxford: Blackwell.

Tobias JH, Chow J, Colston KW \& Chambers TJ 1991 High concentrations of 17 beta-estradiol stimulate trabecular bone formation in adult female rats. Endocrinology 128 408-412.

Turner RT, Evans GL \& Wakley GK 1994a Reduced chondroclast differentiation results in increased cancellous bone volume in estrogen-treated growing rats. Endocrinology 134 461-466.

Turner RT, Riggs BL \& Spelsberg TC $1994 b$ Skeletal effects of estrogen. Endocrine Reviews 15 275-300.

Vanderschueren D, Boonen S \& Bouillon R 1998 Action of androgens versus estrogens in male skeletal homeostasis. Bone 23 391-394.

Veldhuis JD 1998 Neuroendocrine control of pulsatile growth hormone release in the human: relationship with gender. Growth Hormone and IGF Research 8 (Suppl B) 49-59.

Vidal O, Kindblom LG \& Ohlsson C 1999 Expression and localization of estrogen receptor-beta in murine and human bone. Journal of Bone and Mineral Research 14 923-929.

Wakley GK, Evans GL \& Turner RT 1997 Short-term effects of high dose estrogen on tibiae of growing male rats. Calcified Tissue International $6037-42$.

Wang L, Banu J, McMahan CA \& Kalu DN 2001 Male rodent model of age-related bone loss in men. Bone 29 141-148.

Wilkinson DG 1992 Whole mount in situ hybridization of vertebrate embryos. In In situ Hybridization: a Practical Approach, pp 75-83. Ed. DG Wilkinson. Oxford: IRL Press.

Windahl SH, Norgard M, Kuiper GG, Gustafsson JA \& Andersson G 2000 Cellular distribution of estrogen receptor beta in neonatal rat bone. Bone 26 117-121.

Wronski TJ, Walsh CC \& Ignaszewski LA 1986 Histologic evidence for osteopenia and increased bone turnover in ovariectomized rats. Bone 7 119-123.

Yamashiro T \& Takano-Yamamoto T 1998 Differential responses of mandibular condyle and femur to oestrogen deficiency in young rats. Archives of Oral Biology 43 191-195.

Received 6 November 2003

Accepted 3 December 2003

Made available online as an

Accepted Preprint 19 December 2003 